\title{
EFFECTS OF STOCKING DENSITY AND PROTEIN LEVEL IN DIET ON GROWTH PERFORMANCE, SURVIVAL RATE AND FEED EFFICIENCY OF NILE TILAPIA (OREOCHROMIS NILOTICUS L.) FRY MONOSEX DURING THE NURSERY PERIOD.
}

\author{
Ramadan A. Abou-Seif \\ Central Lab. For Aquaculture Research, Abbassa, \\ Abou- Hammad, Sharkia Governorate, Egypt.
}

Key words: Nile tilapia, stocking density, protein level nursery, rearing period.

\section{ABSTRACT}

The effects of stocking density and dietary protein levels on growth performance, larval survival and feed utilization efficiency of Nile tilapia (O. niloticus $\quad$ L.) fry monosex $(0.014 \mathrm{~g}$ average initial body weight) were investigated in a single-stage nursery-rearing system using 1389 and 2778 hatchlings/ $\mathrm{m}^{3}$ as stocking densities within each density $29.71,34.43$ and $39.11 \%$ dietary protein levels. Twelve fiberglass tanks (180 liter volume for each) on a flow- through system (100\%/day)were used to represent the two stocking densities and the three protein levels in replicates. The dietary treatments were fed 7 days/week (twice daily) at a rate of $15 \%$ of the total biomass during the $1^{\text {st }} 45$-days then reduced to $10 \%$ of total biomass from days 46 to 75 , after that it was reduced to $5 \%$ of total biomass till the end of the experiment (105 days).

The results revealed that there was significant increase $(P<0.01)$ in growth rate with decreasing stocking density and increasing dietary protein level during all experimental periods. The same trend was also observed for mean body weight (g), specific growth rate (SGR\%/day), condition factor $(\mathrm{k})$ and survival rate (SR \%). The best final mean body weight (g), SGR, K and (SR \%) were recorded in groups of fish stocked in 1389 hatchlings $/ \mathrm{m}^{3}$ and fed on the diet containing $39.11 \% \mathrm{CP}$ ) $\left(\mathrm{T}_{3} \mathrm{SR}_{1}\right)$.

Feed conversion ratio (FCR) was significantly $(\mathrm{P}<0.01)$ decreased (improved) in $T_{3} S R_{1}$ (Lower stocking density with higher dietary protein level) group compared to the other groups. Improvement in FCR was achieved when dietary protein increased, while increasing stocking density increased (not improved) FCR $(\mathrm{P}<0.01)$. On the contrary, protein 
efficiency ratio (PER) was negatively correlated with dietary protein level and stocking density.

The highest net return was achieved with $T_{3} S R_{1}$ (lower stocking density with higher dietary protein) followed in a descending order by fish of $\mathrm{T}_{2} \mathrm{SR}_{2}$ (higher stocking density with medium dietary protein) and $\mathrm{T}_{3} \mathrm{SR}_{2}$ (higher stocking density with higher dietary protein). The lowest net return was recorded by fish of $\mathrm{T}_{1} \mathrm{SR}_{2}$ (higher stocking density with lowers dietary protein).

Results of this study revealed that fish reared at low stocking density (1389 hatchlings $\left./ \mathrm{m}^{3}\right)$ and fed high dietary protein level $(39.11 \%)$ $\mathrm{T}_{3} \mathrm{SR}_{1}$ group may be advisable in a single- stage nursing for production of adequate quality seeds of Nile tilapia monosex in short time with lowest mortality in order to be available as healthy fry at the beginning of the culture season for fish farmers.

\section{INTRODUCTION}

Tilapia is the second most important farmed fish in the world, after carps. Great attention has been paid to tilapia culture in recent years. Despite the great potential of tilapia culture, shortage of fry production to meet the increased global demands remains one of the main obstacles limiting the expansion of intensive culture of these fishes. Information regarding larval culture, especially the effects of stocking density and dietary protein levels on fish fry management is limited, inconsistent and sometimes controversial. For example, Dambo \& Rana (1992) found that the growth rates of Nile tilapia (O. niloticus L.) fry were negatively correlated with stocking density, ranging from 2 to $20 \mathrm{fry} /$ liter. They suggested 5-10 fry/liter as optimal stocking density. Similarly, El- Sayed (2002) considered 5 fry/ liter as optimal stocking density of $O$. niloticus L. On the contrary, Gall \& Bakar (1999) reported that body size of tilapia fry was not affected by stocking densities ranging from 10 to $200 \mathrm{fry} / \mathrm{L}$, when water flow was uniform. Furthermore, El- Sayed (2002) found that the relationship between the survival of Nile tilapia fry and stocking density was negatively correlated.

The protein requirements of fish are ranging from $30 \%$ to $55 \%$ accordirg to fish species, fish size, dietary protein sources and environmental conditions (NRC, 1993). Dietary protein level for high growth performance of Nile tilapia was found to be $32 \%$ for fingerlings (Lovell, 1989), extraprotein in relation to energy in diet cause the use of protein as an energy source, which increases ammonia secretion and 
deteriorate water quality (Prather \& Lovell 1973; Shyong, et al., 1998 ; Hatlen et al. 2005).

Growth, survival, production and feed efficiency of fry and fingerlings in a single- stage nursery - rearing system depends mainly on stocking density and dietary protein level. Therefore, the present study was undertaken to investigate the effects of stocking density and protein level on growth performance, survival rate and feed efficiency of Nile tilapia (O. niloticus L.) fry monosex reared in circular fiberglass tanks during a single-stage nursery- rearing system.

\section{Study site and experimental design:}

\section{MATERIALS AND METHODS}

The present study was carried out at the fish hatchery of Arab Fisheries Company at Abbassa village, Abu- Hammad, Sharkia Governorate, Egypt. Twelve circular fiberglass tanks each of 180 liter volume were used in this study. The twelve tanks represent two stocking densities (250 and 500 hatchlings in 180 liter fiberglass tank) and within each stocking density studied three dietary protein levels $(29.71,34.43$ and $39.11 \%$ ) were tested. Six treatments were applied in the experimental fiberglass tanks. These were (T1SR1) stocked with 250 hatchlings / 180 liter and fed with $29.71 \%$ protein, (T1SR2) stocked with 500 hatchlings / 180 liter and fed with $29.71 \%$ protein, (T2SR1) stocked with 250 hatchlings / 180 liter and fed $34.43 \%$ protein, (T2SR2) stocked with 500 hatchlings / 180 liter and fed with $34.43 \%$ protein, (T3SRI) stocked with 250 hatchlings / 180 liter and fed $39.11 \%$ protein and (T3SR2) stocked with 500 hatchlings / 180 liter and fed $39.11 \%$ protein. Each treatment was performed in duplicate. The water tanks were on a flow- through system at $100 \% /$ day to avoid any harmful effect of water quality parameters that were within the acceptable limits for fish growth and health (Table 1).

\section{Fish and culture facilities:}

Nile tilapia fry were produced from tilapia broodstock kept in the hatchery. Fertilized eggs were removed from the mother's mouths and stocked in hatching jars provided with upward aeration to keep stirring them. After two days from hatching (complete absorption of yolk-sac.), the fry were stocked into 180 - liter circular fiberglass tanks. They were then fed on the tested diets mixed with $17 \alpha$ methyl testosterone (sex controlling) at a dose of $60 \mathrm{mg} / \mathrm{kg}$ diet $(1 \mathrm{~g} 17 \alpha$ methyl testosterone was dissolved in 1 liter ethyl alcohol, then $60 \mathrm{~cm}^{3}$ of this solution were 
sprayed on $1 \mathrm{~kg}$ diet). Three test diets were formulated to contain three levels of protein $(29.71,34.43$ and $39.11 \%)$. Ingredients and proximate composition of the experimental diets are presented in Table (2).

Nile tilapia $(O$. niloticus $L$.) fry $(0.014 \mathrm{~g}$ average weight) were given the mash prepared experimental diets at a daily rate of $15 \%$ of total biomass during ( $1^{\text {st }} 45$-days) then reduced to $10 \%$ of total biomass from days 46 to 75 after that reduced to $5 \%$ of total biomass till end of the experiment (105-days), while the fish were fed 7 days/week (twice daily at $9.00 \mathrm{am}$ and $3.00 \mathrm{pm}$ ). The amount of feed was bi-weekly adjusted according to the changes in body weight throughout the experimental period (105-days).

At the post-larvae stages, hatchlings were much sensitive and very small in size. So, subsampling techniques for avoiding the great loss and harmful stress on hatchings should be used. The weight per fish were calculated by dividing the subsamples weight on the total number of hatchlings per sample to produce the average weight per hatchling. While the total length of hatchlings were measured individually to the nearest millimeter by using the millimetric petry disches.

Growth performance parameters were measured by using the following equations.

Specific growth rate $(S G R)=\frac{\mathrm{LnW}_{2}-\operatorname{Ln} \mathrm{W}_{1}}{\mathrm{t}} \times 100$

Where: $\mathrm{Ln}=$ the natural $\log , \mathrm{W}_{1}=$ initial weight $(\mathrm{g})$

$\mathrm{W}_{2}=$ the final fish weight in "grams" and $t=$ period in days.

Relative growth rate (RGR) $=\left(\frac{W_{2}-W_{1}}{W_{1}}\right)$

Whore: $W_{1}=$ initial weight and $W_{2}=$ final weight in "grams"

Mass weight gain (WG) (net increment) $=$ final weight (g)-initial weight (g)

Condition factor $(\mathrm{K})=$ weight $/(\mathrm{L})^{3} \times 100$.

Feed conversion ratio $(F C R)=$ feed ingested $(\mathrm{g}) /$ weight gain $(\mathrm{g})$

Protein efficiency ratio (PER) = weight gain $(\mathrm{g}) /$ protein ingested $(\mathrm{g})$ 


\section{Statistical analysis:}

The statistical analysis of data was carried out by applying the computer program, SAS (2000) by adopting the following model.

$$
\text { Yijk }=\mu+R i+\alpha j+E i j k
$$

Where, Yijk $=$ the observation on the $i j k^{\text {th }}$ fish reared in the $j^{\text {th }}$ treatment for the $\mathrm{i}^{\text {th }}$ replicate; $\mu=$ overall mean, $\mathrm{Ri}=$ the effect of $\mathrm{i}^{\text {th }}$ replicate; $\alpha \mathrm{j}=$ the effect of $j^{\text {th }}$ treatment and Eijk $=$ random error.

Differences among means were tested for significance according to Duncan's multiple range test (1955).

\section{RESULTS AND DISCUSSION}

\section{Growth performance:}

At stocking, all hatchlings were of the same age group with a mean length and weight of $0.9 \pm 0.003 \mathrm{~cm}$ and $0.014 \pm 0.001 \mathrm{~g}$, respectively. Results of body weight (BW) as affected by stocking density (1389 and 2778 hatchling/ $\mathrm{m}^{3}$ ) and dietary protein levels $(29.71,34.43$ and $39.11 \% \mathrm{CP}$ ) tested are illustrated in Table (3). As described in this table, average $\mathrm{BW}$ at all experimental periods (0-105-day) decreased significantly $(\mathrm{P}<.0 .01)$ as the fish stocking density increased from 1389 to 2778 hatchling $/ \mathrm{m}^{3}$ within each dietary protein level tested, while the reverse was true with increasing the dietary protein level from 29.71 to $39.11 \% \mathrm{CP}$ in the diets. These results are in agreement with those reported by Abdel- Hakim et al. (200i) who found that BW of Nile tilapia $(27.11-29.02 \mathrm{~g})$ increased significantly with increasing the dietary protein level and decreasing the stocking density. Also, Al- Azab (2001) came to the conclusion that higher tilapia stocking densities released negative effects on its body weight and length, where body weight and body length decreased as the stocking density increased.

Results in Table (3), showed that averages of specific growth rate (SGR) of monosex Nile tilapia fry during the whole experimental period (0-105-day) were 4.78, 4.25, 4.94, 4.73, 5.36 and 4.88 for $\mathrm{T}_{1} \mathrm{SR}_{1}, \mathrm{~T}_{1} \mathrm{SR}_{2}$, $T_{2} S_{1}, T_{2} S R_{2}, T_{3} S R_{1}$ and $T_{3} S_{2}$, respectively and the differences between these values were significant $(P<0.01)$. These results indicate that within each protein level fed decreasing the stocking density improved SGR records and the improvement was more pronounced at higher protein levels. These findings may be due to competition for food and habitat due to higher density of fish (Islam et al., 2002; Rahman and Rahman, 2003). These results are in accordance with the findings of El- Sayed (2002), who reported that SGR of Nile tilapia (with average initial weight $0.016 \mathrm{~g}$ ) 
reared in fiberglass tanks, in a closed, recalculating indoor system for 40 days, were negatively correlated with stocking density and this may be due to social stress causing chronic stress response. In agreement with the present findings, Barcellos et al. (1999) reported that the resting plasma cortical concentration of Nile tilapia fingerlings increased with increasing density of fish, indicating a chronic stress response, attributable to social stress. Furthermore, King et al. (2000) cleared that stress due to space availability was the primary factor inhibiting the growth of summer flounder (Paralichthys dentatus L.) larvae stocked at high densities. Results of Rahman et al. (2005), indicated that SGR of fingerlings of Tor putitora $(0.012 \mathrm{~g})$ was also negatively correlated with stocking density.

As shown in Tabie (3), average SGR values of monosex Nile tilapia were 4.25 and 4.88 for $T_{1} S_{2}$ and $T_{3} S_{2}$, respectively, with significant $(\mathrm{P} \leq 0.01)$ differences between these values. These results indicate that fish fed higher protein level and stocked at higher densities $\left(\mathrm{T}_{3} \mathrm{SR}_{2}\right)$ grow better than those fed lower portion level and also stocked at higher densities $\left(\mathrm{T}_{1} \mathrm{SR}_{2}\right)$. They are in agreement with Abdel- Hakim and Moustafa (2000) who indicated that SGR of Nile tilapia reared in cages was improved almost significantly with each increase in the dietary protein level. fed from 20 to $32 \%$ protein. Also, the same trend was observed for the relative growth rate (RGR) and the averages of daily gain in weight (DWG) during the whole experimental period. Similar findings were reported by Rahman et al. (2005) who noticed that growth in terms of length, weight, weight gain and SGR of fingerlings of Tor Putitora reared in nursery ponds were significantly higher in ponds stocked with 0.6 million hatchling/ha than those from the ponds stocked with 0.8 and 1.0 million hatchlings/ha respectively.

Values of condition factor $(\mathrm{K})$ ranged from 1.42 to 1.9 at the end of the experimental period, with significant $(\mathrm{P}<0.01)$ differences between the different treatments (Table 3 ). The best $K$ value was recorded with $\mathrm{T}_{3} \mathrm{SR}_{1}$ where fish reared at the lowest density (1389 hatchlings $\left./ \mathrm{m}^{3}\right)$ and fed the highest dietary protein level $(39.11 \% \mathrm{CP})$. On the other hand, fish kept in the highest density ( 2778 hatchlings $/ \mathrm{m}^{3}$ ) and fed the lowest dietary protein level $(29.11 \% \mathrm{CP})$ showed the worst $\mathrm{K}$ records. These results indicate that the condition factor improved with the decrease in stocking density and increase in the dietary protein level. These findings may be attributed to the availability of adequate food and space for fry reared. 
Results presented in table $(3)$ revealed significant $(\mathrm{P}<0.05)$ effects of stocking density and dietary protein levels on larval survival and growth performance. Fish survival improved almost significantly $(\mathrm{P}<$ 0.05 ) with each decrease in the stocking density and increasing the dietary protein levels tested. The highest value of survival (96.5\%) was obtained with $T_{3} S_{1}$, while the lowest $(88 \%)$ was observed for $T_{1} S_{2}$. Although the survival rate (SR) of $T_{1} S_{2}$ was numerically lower than that of $T_{3} S_{1}$ with significant difference $(P<0.05)$, there were insignificant differences (P> 0.05) between $S R$ of $T_{1} S R_{1}$ and $T_{1} S R_{2}$, between $S R$ of $T_{1} S R_{2}$ and $T_{2} S R_{2}$, between $S R$ of $T_{3} S R_{1}$ and $T_{3} S R_{2}$ and between $S R$ of $T_{2} S R_{1}$ and $\mathrm{T}_{3} \mathrm{SR}_{2}$. These results are in accordance with those reported by El- Sayed (2002) who found that survival rate of Nile tilapia $(0.016 \mathrm{~g})$ were negatively correlated with stocking density. On the other hand, AbdelHakim et al. (2001) and Al-Azab (2001) reported that both protein level fed and stocking density had no remarkable effects on tilapia survival.

The relative increase in mortality at 2778 hatchlings $/ \mathrm{m}^{3}$ (higher stocking density) and $29.71 \% \mathrm{CP}$ (lowest dietary protein) $(12.0 \%$ mortality, $\mathrm{P}<0.05$ ) was most likely due to cannibalism (not stocking density) as has been reported with other tilapia species, including $O$. mossambicus (Macintosh \& De Silva, 1984). O. niloticus (Dambo and Rana, 1992) and tilapia hybrids (Macintosh \& De Silva, 1984). These results demonstrated that cannibalism could be a main cause of tilapia fry mortality.

\section{Food utilization:}

Results in Table (4) show average feed conversion ratio (FCR) values during the whole experimental period (0-105-days) of fish stocked at high- densities were significantly $(P<0.01)$ higher (not improved) than those of fish stocked at lower- densities at 29.71, 34.43 and $39.11 \% \mathrm{CP}$. This indicates that decreasing the stocking density will provide a more efficient utilization of dietary protein for the growth of fish. Improvement of FCR at decreasing stocking density had been observed in other studies (Abdel- Hakim and Moustafa 2000; Abdel-Hakim et al. 2001 ; Al- Azab 2001): In this connection, the results of Rahman, et al. (2005) are in agreement with the present findings. They reported that FCR values of $T$. putitora fingerlings reared in nursery ponds improved significantly at lower stocking density.

As illustrated in Table (4), the average of FCR of fish fed the high- dietary protein level were significantly lower (better) than those of fish fed the low- dietary protein level at both stocking densities (1389 and 
2778 hatchlings $/ \mathrm{m}^{3}$ ). This indicates that, the FCR improved with the increase in dietary protein level fed. These results are in accordance with those reported by Abdel- Hakim and Moustafa (2000) and Abdel- Hakim et al. (2001) who reported that FCR values of Nile tilapia reared in cages improved significantly with increasing the protein level fed from 20 to $32 \%$ and the improvernents in FCR were more pronounced at lower stocking densities $\left(80\right.$ and $\left.100 \mathrm{fish} / \mathrm{m}^{3}\right)$ compared to higher ones $(120$ or $140 \mathrm{fish} / \mathrm{m}^{3}$ ). Hammer et al. (2006) and Wange et al. (2006) also showed a similar trend. On the other hand, Watanabe et al. (1990) showed that FCR of monosex Florida red tilapia held in cages did not differ at densities that ranged from 100 to $300 \mathrm{fish} / \mathrm{m}^{3}$.

Averages of protein efficiency ratio (PER) of fish tended to increase at low dietary protein level at all stocking densities tested. Also there was significant differences $(\mathrm{P}<0.01)$ among the same protein level, except at $\mathrm{T}_{2} \mathrm{SR}_{1}, \mathrm{~T}_{2} \mathrm{SR}_{2}(34.43 \% \mathrm{CP})$, which showed no significant differences ( $P>0.05$ )as shown in Table (4). This indicates that PER values were negatively correlated with dietary protein level and stocking density. Similar results were obtained by Abdel- Hakim et al. (2001) who reported that, the average PER records of Nile tilapia $(27.11-29.02 \mathrm{~g}$ ) stocked in fiberglass tanks at densities of 50 and $100 \mathrm{fish} / \mathrm{m}^{3}$ decreased from 1.60 to 1.09 , respectively. Also, Kim and Lee (2005) confirmed that PER and protein retention of fish decreased with increasing dietary protein level. They found that PER decreased from 3.56, 3.43, 2.75 and 2.59 as dietary protein level increased from $22 ; 32 ; 42$ and $52 \%$ in fish diet. In accordance with the present results, El- Dahhar et al. (1999) reported a significant decrease in PER as dietary protein level increased. They found that PER decreased from 3.56 to 1.34 as dietary protein level increased from 14 to $38 \%$ in Nile Tilapia diets.

\section{Economic efficiency:}

From the economical point of view, results in Table (5) show that the percentages of net returns relative to : total costs for different treatments were $305.88,284.73$; and 288.55. 333.08, 339.24 and 321.97\% for $T_{1} S R_{1}, T_{1} S R_{2}, T_{2} S R_{1}, T_{2} S_{2}, T_{3} S_{1}$ and $T_{3} S R_{2}$, respectively. These results indicated that the highest benefits were obtained by fish of $T_{3} S R_{1}$ (lower stocking density with higher dietary protein) followed in a descending order by those of $\mathrm{T}_{2} \mathrm{SR}_{2}$ (higher stocking density with medium dietary protein) and $\mathrm{T}_{3} \mathrm{SR}_{2}$ (higher density with higher dietary protein). The lowest net returns relative to total costs was recorded by fish of $T_{1} S_{2}$ (higher stocking density with lower dietary protein). These 
results are in accordance with those of Rahman et al. (2005) working with mahseer (Tor putitora) fingerlings reared in ponds for 8 weeks. They found that higher growth, survival and benefits of fingerling were obtained at a density of 0.6 million hatchlings/ha than those from 0.8 and 1.0 million hatchlings/ha.

In the present study, a significantly higher number of fry were produced in tanks stocked with 2778 hatchlings $/ \mathrm{m}^{3}$ than those from the tanks stocked with 1389 hatchlings $/ \mathrm{m}^{3}$, at each dietary protein level tested. Despite this, consistent higher net returns to total costs were obtained with fish of $T_{3} S R_{1}$ than those of $T_{2} S R_{2}$ and $T_{3} S R_{2}$. The highor market price of the relatively larger fry (suitable for stocking grow- out ponds) were produced in $T_{3} S R_{1}$, substantially increased the net return relative to total costs compared to relatively smaller fry that produced in other groups with higher stocking densities.

\section{Recommendation:}

Finally, it can be concluded that growth, survival and feed utilization of Nile tilapia fry were inversely related to the stocking density of hatchlings. In all respects, 1389 hatchlings $/ \mathrm{m}^{3}$ with $39.11 \%$ protein in the diet $\left(\mathrm{T}_{3} \mathrm{SR}_{1}\right)$ showed highest values of growth parameters, survival and income compared to higher stocking rates at each dietary protein level. Stocking density of 1389 hatchlings $/ \mathrm{m}^{3}$ with $39.11 \mathrm{CP}$ may be advisable for rearing of Nile tilapia fry for 15 weeks in a single- stage nursing system, for production of adequate quality seeds of Nile tilapia in shorter time with lower mortality rates in order to be available as healthy fry at the beginning of the culture season for fish farmers.

\section{REFERENCES}

Abdel- Hakim, N.F. and Moustafa, S.T. (2000). Performance of Nile tilapia ( $O$. niloticus) raised in cages as affected with stocking density and dietary protein level. Egypt. J. of Aquatic Bio. and fish., 4: 95.

Abdel- Hakim, N.F.; Hussein, M.S.; Bakeer, M. N. and Soltan, M.A. (2001). Effect of protein level and stocking density on growth performance of Nile tilapia (O. niloticus) cultured in tanks. Egypt. J. Nut. and Feeds, 4: 763-780. 
Al- Azab, A.A. (2001). Studies on feeding of Nile tilapia under intensive culture condition, Ph. D. Thesis, Fac. of Agric., Al- Azhar Univ.

Barcellos, L.G.J.; Nicolaiewsky, S.; De Souzs, S.M.H. and Luther, F. (1999). The effects of stocking density and social interaction of acute stress response in Nile tilapia (Oreachromis niloticus L.) fingerlings. J. Aquacult. Res., 30: 881-892.

Dambo, W.B. and Rana, K.J. (1992). Effect of stocking density on growth and survival of Nile tilapia, Oreochromis nilotieus, (L.) fry in the hatchery. J. Aquacult. and Fish. Manag., 23: 71-80.

Duncan, D.B. (1955). Multiple range and multiple F tets. Biometerics, $11: 1$.

El- Dahhar, A. A.; Zeweil, H.S. and El- Tawil, N.E. (1999). Protein and energy requirements of fry Nile tilapia ( $O$. niloticus) fry maintenance and maximum growth. Egypt. J. Nut. and feeds 2 (Special Issue): 807.

El- Sayed, A. M. (2002). Effects of stocking density and feeding levels on growth and feed efficiency of Nile tilapia (Oreochromis niloticus L.) fry. J. Aquacul. Reas., 33: 621-626.

Gall, G.A.E. and Bakar, Y. (1999). Stocking density and tank size in the design of breed improvement programs for body size of tilapia. J. Aquacult., 173: 197-205.

Hammer, H.S.; Laweruce, A.J. and Desmand, R. (2006). Effect of dietary protein on consumption, survival, growth and production of the see urchin, (Lytechinus varieatus). Aquacult., 254 (1/4): 495483.

Haque, M.Z., Rahman, M.A., Hossain, M.M. and Rahman, M.A. (1994). Effects of stocking densities on the growth and survival of mirror carp, Cyprinus carpio var. specularis in rearing ponds. Banglad. J. Zool, 22:109-116.

Hatlen, B.; Hell, B.G. and Hell, S.J. (2005). Growth, feed utilization and body composition in two size groups of Atlantic halibirt 
EFFECTS OF STOCKINGG DENSITY AND PROTEIN LEVEL 79 IN DIET ON NILE TILAPIA FRY DURING THE NURSERY PERIOD

(Hippoglossus hippoglossus) fed diets differing in protein and carbohydrate content. Aquacult., 249: 401-408.

Islam, M.S.; Dewan, S.; Hussain, M.G., Hossain, M.A. and Mazid, M.A. (2002). Feed utilization and wastage in semi- intensive pond culture of mahseer, Tor putitora (Ham.) Banglad. J. fish Res. $6: 1-9$.

Jobling, M. (1983). A short review and critique of methodology used in fish growth and nutrition studies. J. Fish. Biol., 23: 685-703.

Kim, L. O. and Lee S. M. (2005). Effects of the dietary protein and lipid levels on growth and body composition of bagrid catfish, Pseudobagrus fulvidraco. Aquacult., 243: 323-329.

King, N. J.; Howell, W.H., Huber, M. and Bengtson, D.A. (2000). Effects of stocking density on Laboratory - scale production of Summer flounder (Paralichthys dentatis). J. World Aquacult. Soc., 31: 436-445.

Lovell, R.T. (1989). Nutrition and feeding of fish Van. Nostrand Reinhold, New York, NY.

Macintosh, D.L. and De Silva, S.S. (1984). The infuence of stocking density and food ration of fry survival and growth in Oreochromis mossambicus and $O$. niloticus $\mathrm{X} O$. aureus male hybrids reared in a closed circulated system. J. Aquacul., 41: 345-358.

NRC (National Research Council) (1993). Nutrient Requirements of fish. Nat. Acad. Press, Washing., DC.

Prather, E.E. and Lovell, R.T. (1973). Response of intensively fed channel catfish to diets containing various protein- energy ratio. Proceed. of the $27^{\text {th }}$ Scuth- East. Assoc.of Game and Fish Commissioner 27: 455-459.

Rahman, M. R. and Rahman, M.A., (2003). Studies on the growth, survival and production of calbasu (Labeo calbaus Ham.) fry at 
different stocking densities in primary nursing. Bull. Fac. Sci., Univ. Ryuyus, Jpn. 76:245-255.

Rahman, M.A.; Mazid, M.A.; Rahman, M.R.; Noor Kham, M., Hossain, M.A. and Hussain, M.G. (2005). Effect of stocking density on survival and growth of critically endangered mahseer, (Tor putitora Ham.), in nursery ponds. Aquacul., 249: 275-284.

SAS (2000).SAS procedure Guide Statistics, SAS institute Inc., Cary, NC, U.S.A.

Shyong, W.J.; Huang, C.H. and Chen, H.C. (1998). Effects of dietary protein concentration on growth and muscle composition of juvenile Zacco barbata. Aquacul., 167: 35-42.

Wange, Y.; Gou, J.J.; Li, K. and Bureau, D.P. (2006). Effect of dietary protein and energy levels on growth, feed utilization and body composition of cuneate dram (Nibea miichthioides). Aquacult., 252 (214): 183-198.

Watanabe, W.O.; Clark, J.H., Dunham, J.B., Weiklund, R.I. and Olla, B.L. (1990). Culture of Florida red tilapia in merine cages : The effect of stocking density and dietary protein on growth. Aquacutl., 90:123-134. 


\section{EFFECTS OF STOCKING DENSITY AND PROTEIN LEVEL IN DIET ON NILE TILAPIA FRY DURING THE NURSERY PERIOD}

Table (1): Effects of stocking density and dietary protein level on averages water quality parameters (mean $\pm S E$ ) of monosex Nile tilapia fry over the rearing period.

\begin{tabular}{|c|c|c|c|c|c|c|}
\hline \multirow{2}{*}{ Parameters. } & \multicolumn{2}{|c|}{. } & \multicolumn{2}{|c|}{ Treatments } & \multirow[b]{2}{*}{$\mathrm{T}_{3} \mathrm{SR}_{1}$} & \multirow[b]{2}{*}{$\mathrm{T}_{3} \mathrm{SR}_{2}$} \\
\hline & $I_{1} \mathbf{S R}_{1}$ & $\mathrm{~T}_{1} \mathrm{SR}_{2}$ & $T_{2} S_{1}$ & $\mathrm{~T}_{2} \mathrm{SR}_{2}$ & & \\
\hline Water temperature $\left({ }^{\circ} \mathrm{C}\right)$ & $\begin{array}{c}28.1 \\
\pm 2.65^{2}\end{array}$ & $\begin{array}{l}28.41 \\
\pm 2.64^{\prime \prime}\end{array}$ & $\begin{array}{c}28.3 \\
\pm 2.7 !^{\circ}\end{array}$ & $\begin{array}{l}28.53 \\
\pm 2.73^{*}\end{array}$ & $\begin{array}{c}28.35 \\
\pm 2.71^{4}\end{array}$ & $\begin{array}{l}28.69 \\
\pm 2.51^{\prime \prime}\end{array}$ \\
\hline Dissotved oxygen (mg/L) & $\begin{array}{c}6.2 \\
\pm 0.51^{\circ}\end{array}$ & $\begin{array}{c}5.31 \\
\pm 0.49^{\circ}\end{array}$ & $\begin{array}{c}6.01 \\
\pm 0.50^{4}\end{array}$ & $\begin{array}{c}5.11 \\
\pm 0.48^{\Delta b}\end{array}$ & $\begin{array}{c}5.01 \\
\pm 0.51^{\infty}\end{array}$ & $\begin{array}{r}4.83 \\
\pm 0.43^{b}\end{array}$ \\
\hline PH & $\begin{array}{c}7.71 \\
\pm 0.18^{4}\end{array}$ & $\begin{array}{c}7.52 \\
\pm 0.18\end{array}$ & $\begin{array}{c}7.61 \\
\pm 0.19\end{array}$ & $\begin{array}{c}7.41 \\
\pm 0.17^{2}\end{array}$ & $\begin{array}{c}7.31 \\
\pm 0.18^{\circ}\end{array}$ & $\begin{array}{l}7.21 \\
\pm 0.19^{\circ}\end{array}$ \\
\hline Total alkalinity (mgll) & $\begin{array}{l}610.0 \\
\pm 45.0^{\circ}\end{array}$ & $\begin{array}{r}613.0 \\
+36.0^{\circ} \\
\end{array}$ & $\begin{array}{l}630.0 \\
\pm 47.0^{*}\end{array}$ & $\begin{array}{r}615.0 \\
\pm 36.0^{\circ}\end{array}$ & $\begin{array}{r}610.0 \\
\pm 46.0^{*}\end{array}$ & $\begin{array}{l}635.0 \\
\pm 39.0^{4}\end{array}$ \\
\hline Total hardness & $\begin{array}{l}260.0 \\
\pm 15.0^{2}\end{array}$ & $\begin{array}{r}270.0 \\
\pm 15.0^{\circ b}\end{array}$ & $\begin{array}{r}245.0 \\
\pm 13.0^{\circ} \\
\end{array}$ & $\begin{array}{r}215.0 \\
\pm 13.0^{b}\end{array}$ & $\begin{array}{r}220.0 \\
\pm 15.0^{b}\end{array}$ & $\begin{array}{l}230.0 \\
\pm 16.0^{\circ} \\
\end{array}$ \\
\hline
\end{tabular}

a, $b$ means in the same row having the same superscript are not significantly different $(P>0.05)$

Table (2): Composition and proximate analysis of experimental diets containing different lcvels of protein.

\begin{tabular}{|l|c|c|c|}
\hline \multicolumn{1}{|c|}{ Feed ingredients \% } & \multicolumn{3}{c|}{ Experimental diets } \\
\cline { 2 - 4 } & Dict 1 & Diet 2 & Diet 3 \\
& $29.71 \%$ & $34.43 \%$ & $39.11 \%$ \\
\hline Fish meal & 20.0 & 23.5 & 33.5 \\
\hline Soybean meal & 31.0 & 39.0 & 37.0 \\
\hline Wheat bran & 10.5 & 14.0 & 9 \\
\hline Yellow com & 31.5 & 16.5 & 13.5 \\
\hline Starch & 2 & 2 & 2 \\
\hline Vegetable oil & 2 & 2 & 2 \\
\hline Vit. \& Min. mixture & 3 & 3 & 3 \\
\hline Total & 100 & 100 & 100 \\
\hline Chemical composition (on DM basis\%) & & & \\
\hline Dry matter (DM) & 92.70 & 93.01 & 92.95 \\
\hline Crude protein (CP) & 29.71 & 34.43 & 39.11 \\
\hline Ether extract (EE) & 8.9 & 6.3 & 9.2 \\
\hline Crude fiber (CF) & 9.2 & 5.5 & 4.3 \\
\hline Ash & 7.31 & 7.13 & 7.03 \\
\hline NFE ${ }^{2}$ & 44.88 & 46.64 & 40.36 \\
\hline Gross energy $\mathrm{K}$ cal $/ \mathrm{kg}$ diet ${ }^{3}$ & 4682.9 & 4626.3 & 4865.5 \\
\hline
\end{tabular}

'Vitamin \& mineral mixture/ $\mathrm{kg}$ premix : Vitamin $\mathrm{D}_{3}, 0.8$ million IU; $\mathrm{A}, 4.8$ million IU; $\mathrm{E}, 4 \mathrm{~g} ; \mathrm{K}, 0.8 \mathrm{~g} ; \mathrm{BI}, 0.4 \mathrm{~g}$; Riboflavin, $1.6 \mathrm{~g} ; \mathrm{B} 6,0.6 \mathrm{~g}, \mathrm{~B} 12,4 \mathrm{mg}$; Pantothenic acid, $4 \mathrm{~g}$; Nicotinic acid, 8g; Folic acid, $0.4 \mathrm{~g}$ Biotin, $20 \mathrm{mg}, \mathrm{Mn}, 22 \mathrm{~g} ; \mathrm{Zn}, 22 \mathrm{~g} ; \mathrm{Fe}, 12 \mathrm{~g} ; \mathrm{Cu}, 4 \mathrm{~g}$; , $0.4 \mathrm{~g}$; Selenium, $0.4 \mathrm{~g}$ and $\mathrm{Co}, 4.8 \mathrm{mg}$.

${ }^{2} \mathrm{NFE}=$ nitrogen free extract (calculated by difference) .

${ }^{3}$ According to Jobling (1983) as $5.65,9.45$ and $4.11 \mathrm{~K}$ cal / $\mathrm{g}$ for protein lipid and carbohydrate, respectively. P/E ratios ( $\mathrm{mg} \mathrm{CP} / \mathrm{K}$ cal GE) were 63.44, 74.42 and 80.38, respectively. 
Table (3): Effects of stocking density and dietary protein level on the performance (mean \pm SE) of monosex Nile tilapia (O. niloticus L.) fry during the rearing period.

\begin{tabular}{|c|c|c|c|c|c|c|c|}
\hline \multirow[b]{2}{*}{ Stages } & \multicolumn{7}{|c|}{ Treatments } \\
\hline & $\mathbf{T}_{1} \mathrm{SR}_{\mathrm{l}}$ & $\mathbf{T}_{1} \mathbf{S R}_{2}$ & $\mathbf{T}_{2} \mathbf{S R}_{1}$ & $\mathrm{~T}_{2} \mathrm{SR}_{2}$ & $\mathbf{T}_{3} \mathbf{S R}_{\mathbf{1}}$ & $\mathbf{T}_{3} \mathbf{S R}_{2}$ & $\begin{array}{l}\text { Test of } \\
\text { significance }\end{array}$ \\
\hline $\begin{array}{l}\text { Inilial body weight/fish } \\
\text { (g) }\end{array}$ & $\begin{array}{l}0.014 \\
\pm 0.001\end{array}$ & $\begin{array}{c}0.014 \\
\pm 0.001\end{array}$ & $\begin{array}{l}0.014 \\
\pm 0.001\end{array}$ & $\begin{array}{l}0.014 \\
\pm 0.001\end{array}$ & $\begin{array}{l}0.014 \\
\pm 0.001\end{array}$ & $\begin{array}{l}0.014 \\
\pm 0.001\end{array}$ & N.S \\
\hline $\begin{array}{l}\text { Inilial body length } \\
\text { /Iish }(\mathrm{cm})\end{array}$ & $\begin{array}{c}0.9 \\
\pm 0.003\end{array}$ & $\begin{aligned} & 0.9 \\
\pm & 0.003\end{aligned}$ & $\begin{array}{c}0.9 \\
\pm 0.003\end{array}$ & $\begin{array}{c}0.9 \\
\pm 0.003\end{array}$ & $\begin{array}{c}0.9 \\
\pm 0.003\end{array}$ & $\begin{array}{c}0.9 \\
\pm 0.003\end{array}$ & N.S \\
\hline 15- day post stocking & $\begin{array}{c}0.03 \\
\pm 0.001^{2}\end{array}$ & $\begin{array}{c}0.023 \\
\pm 0.001^{b}\end{array}$ & $\begin{array}{c}0.035 \\
\pm 0.001^{\prime}\end{array}$ & $\begin{array}{c}0.03 \\
\pm 0.001^{*}\end{array}$ & $\begin{array}{c}0.031 \\
\pm 0.001^{*}\end{array}$ & $\begin{array}{c}0.026 \\
\pm 0.001^{b}\end{array}$ & * \\
\hline 30- day post stacking & $\begin{array}{c}0.15 \\
\pm 0.003^{\prime}\end{array}$ & $\begin{array}{c}0.086 \\
\pm 0.003^{e}\end{array}$ & $\begin{array}{c}0.15 \\
\pm 0.006^{2}\end{array}$ & $\begin{array}{c}0.12 \\
\pm 0.004^{\mathrm{b}}\end{array}$ & $\begin{array}{c}0.156 \\
\pm 0.006\end{array}$ & $\begin{array}{c}0.127 \\
\approx 0.005^{\circ}\end{array}$ & $* *$ \\
\hline 45- day posi stocking & $\begin{array}{c}0.27 \\
0.007^{b}\end{array}$ & $\begin{array}{c}0.158 \\
\pm 0.00 T^{c}\end{array}$ & $\begin{array}{r}0.30 \\
\pm 0.016^{26}\end{array}$ & $\begin{array}{c}0.255 \\
\pm 0.018^{b}\end{array}$ & $\begin{array}{l}0.384 \\
\pm 0.02^{1}\end{array}$ & $\begin{array}{c}0.33 \\
\pm 0.02^{2}\end{array}$ & ** \\
\hline 60- day post stocking & $\begin{array}{c}0.62 \\
\pm 0.02^{b}\end{array}$ & $\begin{array}{c}0.38 \\
\pm 0.02^{\mathrm{c}}\end{array}$ & $\begin{array}{c}0.73 \\
\pm 0.03^{\infty}\end{array}$ & $\begin{array}{c}0.59 \\
\pm 0.022^{\mathrm{bc}}\end{array}$ & $\begin{array}{c}0.83 \\
\pm 0.04^{n}\end{array}$ & $\begin{array}{c}0.76 \\
\pm 0.045^{2}\end{array}$ & ** \\
\hline 75- day post stocking & $\begin{array}{c}0.91 \\
\pm 0.038^{\mathrm{c}}\end{array}$ & $\begin{array}{c}0.625 \\
\pm 0.037^{d}\end{array}$ & $\begin{array}{c}1.16 \\
\pm 0.053^{b}\end{array}$ & $\begin{array}{c}1.03 \\
\pm 0.06^{b}\end{array}$ & $\begin{array}{c}1.42 \\
\pm 0.07\end{array}$ & $\begin{array}{c}1.13 \\
\pm 0.054^{b}\end{array}$ & ** \\
\hline 90- day post stocking & $\begin{array}{c}1.37 \\
\pm 0.053^{\mathrm{v}}\end{array}$ & $\begin{array}{c}0.89 \\
\pm 0.055^{d}\end{array}$ & $\begin{array}{c}1.58 \\
\pm 0.073^{\circ}\end{array}$ & $\begin{array}{c}1.28 \\
\pm 0.08^{\mathrm{e}}\end{array}$ & $\begin{array}{c}2.4 \\
\pm 0.051^{2}\end{array}$ & $\begin{array}{c}1.62 \\
\pm 0.08^{b}\end{array}$ & $*$ \\
\hline 105- day post stocking & $\begin{array}{c}2.11 \\
\pm 0.042^{c}\end{array}$ & $\begin{array}{c}1.22 \\
\pm 0.06 \mathrm{~J}^{\mathrm{d}}\end{array}$ & $\begin{array}{c}2.5 \\
\pm 0.072^{b}\end{array}$ & $\begin{array}{c}2.01 \\
\pm 0.053^{c}\end{array}$ & $\begin{array}{c}3.91 \\
\pm 0.05^{\prime \prime}\end{array}$ & $\begin{array}{c}2.35 \\
\pm 0.032^{b}\end{array}$ & ** \\
\hline $\begin{array}{l}\text { Final body lcngth / fish } \\
(\mathrm{cm})\end{array}$ & $\begin{array}{c}5.0 \\
\pm 0.63^{b}\end{array}$ & $\begin{array}{l}4.4 ! \\
\pm 0.61^{\circ}\end{array}$ & $\begin{array}{r}5.4 \\
\pm 0.81^{200} \\
\end{array}$ & $\begin{array}{l}5.0 \\
\pm 1.15^{\mathrm{mb}}\end{array}$ & $\begin{array}{c}5.9 \\
\pm 1.25^{\mathrm{a}}\end{array}$ & $\begin{array}{c}5.3 \mathrm{l}^{\mathrm{i}} \\
\pm 0.8 \mathrm{i}^{\mathrm{sb}}\end{array}$ & ** \\
\hline $\begin{array}{c}\text { Daily weight gain } \\
\text { (g/day//ish) }\end{array}$ & $\begin{array}{c}0.02 \\
\pm 0.001^{\mathrm{c}}\end{array}$ & $\begin{array}{c}0.011 \\
\pm 0.001^{\mathrm{d}}\end{array}$ & $\begin{array}{c}0.024 \\
\pm 0.001^{\mathrm{b}}\end{array}$ & $\begin{array}{c}0.02 \\
\pm 0.001^{c}\end{array}$ & $\begin{array}{l}0.037 \\
\pm 0.001^{4}\end{array}$ & $\begin{array}{c}0.022 \\
\pm 0.001^{\circ}\end{array}$ & ** \\
\hline Net inerement & $\begin{array}{c}2.10 \\
\pm 0.08^{d}\end{array}$ & $\begin{array}{c}1.21 \\
\pm 0.091^{\circ}\end{array}$ & $\begin{array}{c}2.49 \\
\pm 0.09^{b}\end{array}$ & $\begin{array}{c}2.00 \\
\pm 0.073^{\mathrm{d}}\end{array}$ & $\begin{array}{c}3.90 \\
\pm 0.091^{2}\end{array}$ & $\begin{array}{c}2.34 \\
\pm 0.051^{\mathrm{c}}\end{array}$ & ** \\
\hline $\begin{array}{l}\text { Specific growth rate } \\
\text { (SGR) }\end{array}$ & $\begin{array}{c}4.78 \\
\pm 0.13^{\mathrm{c}}\end{array}$ & $\begin{array}{c}4.25 \\
\pm 0.13^{\mathrm{d}}\end{array}$ & $\begin{array}{c}4.94 \\
\pm 0.13^{\mathrm{b}}\end{array}$ & $\begin{array}{c}4.73 \\
\pm 0.13^{c}\end{array}$ & $\begin{array}{l}5.36 \\
\pm 0.13^{\mathrm{a}}\end{array}$ & $\begin{array}{l}4.88 \\
\pm 0.13^{\circ}\end{array}$ & ** \\
\hline $\begin{array}{l}\text { Relative growth rale } \\
\text { (ROR) }\end{array}$ & $\begin{array}{l}149.71 \\
\pm 0.19^{\circ}\end{array}$ & $\begin{array}{l}86.14 \\
\pm 0.19^{4}\end{array}$ & $\begin{array}{l}177.57 \\
\pm 0.19^{\circ}\end{array}$ & $\begin{array}{l}142.57 \\
\pm 0.19^{\circ}\end{array}$ & $\begin{array}{l}278.29 \\
\pm 0.19^{\circ}\end{array}$ & $\begin{array}{l}166.86 \\
\pm 0.19^{b}\end{array}$ & $* *$ \\
\hline Initial condition factor & $\begin{array}{c}1.92 \\
\pm 0.001\end{array}$ & $\begin{array}{c}1.92 \\
\pm 0.001\end{array}$ & $\begin{array}{c}1.92 \\
\pm 0.001\end{array}$ & $\begin{array}{c}1.92 \\
\pm 0.001\end{array}$ & $\begin{array}{c}1.92 \\
\pm 0.001\end{array}$ & $\begin{array}{c}1.92 \\
\pm 0.001\end{array}$ & N.S \\
\hline Final condition factor & $\begin{array}{c}1.68 \\
\pm 0.07^{\mathrm{b}}\end{array}$ & $\begin{array}{l}1.42 \\
\pm 0.06^{\circ}\end{array}$ & $\begin{array}{c}1.58 \\
\pm 0.07^{\circ 4}\end{array}$ & $\begin{array}{c}1.61 \\
\pm 0.08^{c}\end{array}$ & $\begin{array}{c}1.9 \\
\pm 0.07^{2}\end{array}$ & $\begin{array}{c}1.57 \\
\pm 0.08^{\circ \mathrm{d}}\end{array}$ & ** \\
\hline Survival rate \% & $\begin{array}{l}90.0 \\
\pm 0.11^{\circ}\end{array}$ & $\begin{array}{c}8 B .0 \\
\pm 0.11^{\text {五 }}\end{array}$ & $\begin{array}{c}92.5 \\
\pm 0.11^{b}\end{array}$ & $\begin{array}{c}88.5 \\
\pm 0.31^{c}\end{array}$ & $\begin{array}{c}96.5 \\
\pm 0.11^{2}\end{array}$ & $\begin{array}{c}94.5 \\
\pm 0.11^{\text {at }}\end{array}$ & * \\
\hline
\end{tabular}

$a, b, c, d$ means within each raw having different letters are significantly different at $(P<0.05)$ otherwise they are not $. N S=$ non significance $*=P<0.05^{* *}=P<0.01$ 


\section{EFFECTS OF STOCKING DENSITY AND PROTEIN LEVEL 83 IN DIET ON NILE TILAPIA FRY DURING THE NURSERY PERIOD}

Table (4): Effects of stocking density and dietary protein levels on feed efficiency (mean \pm SE) of monosex Nile tilapia fry during the rearing period.

\begin{tabular}{|c|c|c|c|c|c|c|c|}
\hline \multirow{2}{*}{ Traits } & \multicolumn{7}{|c|}{ Treatments } \\
\hline & $T_{1} S_{R_{1}}$ & $\mathrm{~T}_{1} \mathrm{SR}_{2}$ & $\mathrm{~T}_{2} \mathrm{SR}_{1}$ & $\mathrm{~T}_{2} \mathrm{SR}_{2}$ & $\mathrm{~T}_{3} \mathrm{SR}_{1}$ & $\mathrm{~T}_{3} \mathrm{SR}_{2}$ & $\begin{array}{c}\text { Test of } \\
\text { significance }\end{array}$ \\
\hline Feed intake $\mathrm{g} /$ fish & $\begin{array}{c}3.46 \\
\pm 0.051^{\mathrm{c}}\end{array}$ & $\begin{array}{c}2.2 \\
\pm 0.031^{\mathrm{d}}\end{array}$ & $\begin{array}{c}4.05 \\
\pm 0.05^{\mathrm{b}}\end{array}$ & $\begin{array}{c}3.36 \\
\pm 0.031^{\mathrm{c}}\end{array}$ & $\begin{array}{c}5.04 \\
\pm 0.021^{\prime}\end{array}$ & $\begin{array}{c}4.08 \\
\pm 0.023^{\mathrm{b}}\end{array}$ & ** \\
\hline Protein intake $g /$ fish & $\begin{array}{c}1.03 \\
\pm 0.05^{\mathrm{d}}\end{array}$ & $\begin{array}{c}0.65 \\
\pm 0.05^{\mathrm{e}}\end{array}$ & $\begin{array}{c}1.39 \\
\pm 0.031^{\mathrm{c}}\end{array}$ & $\begin{array}{c}1.15 \\
\pm 0.033^{\mathrm{d}}\end{array}$ & $\begin{array}{c}1.97 \\
\pm 0.061^{2}\end{array}$ & $\begin{array}{c}1.59 \\
\pm 0.015^{b}\end{array}$ & ** \\
\hline FCR & $\begin{array}{c}1.65 \\
\pm 0.01^{\mathrm{c}}\end{array}$ & $\begin{array}{c}1.83 \\
\pm 0.01^{4}\end{array}$ & $\begin{array}{c}1.63 \\
\pm 0.01^{c}\end{array}$ & $\begin{array}{c}1.68 \\
\pm 0.01^{\mathrm{c}}\end{array}$ & $\begin{array}{c}1.29 \\
\pm 0.01^{\mathrm{d}}\end{array}$ & $\begin{array}{c}1.75 \\
\pm 0: 01^{\mathrm{b}}\end{array}$ & ** \\
\hline PER & $\begin{array}{c}2.03 \\
\pm 0.05^{\mathrm{a}}\end{array}$ & $\begin{array}{c}1.85 \\
\pm 0.05^{\mathrm{b}}\end{array}$ & $\begin{array}{c}1.78 \\
\pm 0.05^{b}\end{array}$ & $\begin{array}{c}1.73 \\
\pm 0.05^{\mathrm{bc}}\end{array}$ & $\begin{array}{c}1.97 \\
\pm 0.05^{n}\end{array}$ & $\begin{array}{c}1.47 \\
\pm 0.05^{c}\end{array}$ & ** \\
\hline
\end{tabular}

$a, b, c, d$ means within each raw having different letters were significantly different at $(P$ $<0.01$ ). 
Table ( 5 ): Economical evaluation of the experimental treatments.

\begin{tabular}{|c|c|c|c|c|c|c|}
\hline \multirow{2}{*}{ Lis $x_{i l}$} & \multicolumn{6}{|c|}{ Treatments } \\
\hline & $\overline{T_{1} S_{R_{1}}}$ & $\overline{T_{1} S R_{2}}$ & $T_{2} S R_{1}$ & $\mathrm{~T}_{2} \mathrm{SR}_{2}$ & $T_{3} S R_{1}$ & $\overline{T_{3} \mathrm{SR}_{2}}$ \\
\hline Stockingrate (No/m $)$ & 1389 & 2778 & 1389 & 2778 & 1389 & 2778 \\
\hline Average size at stocking $(\mathrm{g})$ & 0.014 & 0.014 & 0.014 & 0.014 & 0.014 & 0.014 \\
\hline Average size at harvest (g) & 2.11 & 1.22 & -2.5 & 2.01 & 3.91 & 2.35 \\
\hline Total weight gain (g/fish) & 2.10 & 121 & $2 . \overline{49}$ & 2.00 & 3.90 & 2.34 \\
\hline Survival rade (\%) & 90.0 & B8.0 & 92.5 & 88.5 & 96.5 & 94.5 \\
\hline Total No. at harvest $\mathrm{m}^{\prime}$ & 1250.1 & 2444.64 & 1284.8 & 2458.5 & 1340.4 & 26252 \\
\hline \multicolumn{7}{|l|}{ A- cperating costs } \\
\hline Fish fry 20 LE/ 1000 fry & 27.78 & 55.56 & 27.78 & 55.56 & 27.78 & 55.56 \\
\hline Costs of one ton feed (L.E) & 1750 & 1750 & 2100 & 2100 & 2450 & 2450 \\
\hline Relative to control (\%) & 100 & 100 & $\overline{120}$ & 120 & $\overline{140}$ & 140 \\
\hline Increase in feed cost (L.E'ton\%) & 0.00 & 0.00 & 20.00 & 20.00 & 40.00 & 40.00 \\
\hline Feed intake ( $\mathrm{g}$ feed/fish) & 3.46 & 2.2 & $\overline{4.05}$ & 3.36 & 5.04 & 4.08 \\
\hline Total food $\left(\mathrm{kg} / \mathrm{m}^{3}\right)$ & $\overline{4.81}$ & 6.11 & 5.63 & 9.33 & 7.00 & 11.33 \\
\hline Cost of food/m $\mathrm{m}^{2}$ (L.E) & 8.42 & 10.69 & 11.82 & 19.59 & 17.15 & 27.76 \\
\hline Screen, pump and labor L.E. $/ \mathrm{m}^{3}$ & 10.0 & 10.0 & 10.0 & 10.0 & 10.0 & 10.0 \\
\hline Total costs/m (L.E) & $46 \overline{2}$ & 76.25 & 49.6 & 85.15 & 54.93 & 93.32 \\
\hline Feed conversion ratio (FCR) & 1.65 & 1.83 & 1.63 & 1.68 & 1.29 & 1.75 \\
\hline Fced cost to produce $1 \mathrm{~kg}$ fish (L.E) & 2.89 & 3.20 & 3.42 & 3.53 & 3.16 & 4.29 \\
\hline Relative to control $(\%)$ & 100 & 100 & 118.34 & 110.31 & 109.34 & 134.06 \\
\hline B-Total returns/m ${ }^{3}$ (L.E.) & 187.52 & .293 .36 & 192.72 & 368.77 & 241.27 & 393.78 \\
\hline Net relums/ m & 141.32 & .217 .11 & 143.12 & 283.62 & 186.34 & 300.46 \\
\hline C-Net retums to operating cost & 305.88 & 284.73 & $288.55^{\circ}$ & 333.08 & 33924 & 321.97 \\
\hline
\end{tabular}

Local market price of feed and fingerlings when the experiment was done

One ton feed $29.7 \%$ C.P.

I 750 L.E.

$$
\begin{array}{ll}
34.3 \% & 2100 \text { L.E. } \\
39.1 \% & 2450 \text { L.E. }
\end{array}
$$

Fingerling by weight of $1-2 \mathrm{~g} \quad 120$ L.E.

$$
\begin{array}{ll}
2-3 \mathrm{~g} & 150 \mathrm{~L} . \mathrm{E} . \\
3-4 \mathrm{~g} & 180 \text { L.E. }
\end{array}
$$

* Feed cost to produce $1 \mathrm{~kg}$ fish= Feed price $\times$ FCR. 